\title{
S11 - Modelo computacional para el estudio y predicción del clima
}

\author{
Enrique Pazos \\ Escuela de Ciencias Físicas y Matemáticas, Universidad de San Carlos de Guatemala
}

*Autor al que se dirige la correspondencia: pazosenrique@gmail.com

\section{Resumen}

- $\mathrm{n}$ vista del inminente cambio climático global, es necesario contar con modelos matemáticos regionales y gloCales que puedan proyectar con detalle las tendencias futuras de temperatura, humedad, precipitación, viento y absorción de radiación solar, entre otras. Con esta motivación, presentamos los resultados preliminares de un modelo físico cuantitativo que describe el movimiento, densidad y temperatura de masas de aire en la atmósfera. El modelo se basa en la solución numérica de las ecuaciones de Euler para aire seco, por medio del método de volúmenes finitos. El modelo es utilizado para describir la evolución en el tiempo de masas de aire tibio y frío en un perfil bidimensional que representa una sección vertical de la atmósfera. Se incluye también el efecto de la curvatura del suelo por medio de coordenadas que siguen el perfil topográfico del terreno. En los resultados de la simulación es posible observar que el movimiento del aire genera diferentes patrones en las corrientes de viento y distribución de temperatura en la atmósfera, los cuales afectan distintos lugares dependiendo de la velocidad de advección de la masa de aire. Este estudio es un primer paso en la predicción a futuro de los efectos del cambio climático en el territorio de Guatemala, los cuales son necesarios para poder tomar medidas y políticas de adaptación y mitigación.

Palabras claves: Clima, modelo numérico, hidrodinámica, volúmenes finitos

\section{Abstract}

$\mathrm{D}$ ue to the imminent global climate change, it is a necessity to have global and regional mathematical models that will be able to make detailed projections of future tendencies of temperature, humidity, precipitation, wind and absorption of solar radiation, among others. With this motivation, we present preliminary results of a quantitative physical model that describes the motion, density and temperature of air masses in the atmosphere. The model is based on the solution of Euler's equations for dry air, using the finite volume method. The model is used to compute the time evolution of warm and cold air masses in a bi-dimensional profile that represents a vertical section of the atmosphere. The effect of soil curvature is also taken into account by means of terrain following coordinates. In the results of the simulations, it is possible to observe that the motion of the air generates different patterns in the wind currents and temperature distribution in the atmosphere, which affect different places depending on the advection speed of the air mass. This study is a first step in the prediction of the climate change effects on the Guatemalan territory, which are necessary in order to take adaptation and mitigation measures and policies.

Keywords: Climate, numerical model, hydrodynamics, finite volume 